$\begin{array}{cc}\text { Araştırma Makalesi / Research Article } & \text { Harran Tarım ve Gıda } \\ \text { Gilimleri Dergisi (2016) } & \text { 20(4): 330-337 } \\ \text { Kabul tarihi: } 17.06 .2016 & 20.09 .2016\end{array}$

\title{
Farklı İnokulantların Arpa Silajlarının Yem Değerine Etkileri
}

\section{Ayfer BOZKURT KIRAZ1* ${ }^{*}$, Hasan Rüştü KUTLU²}

\author{
${ }^{1}$ Harran Üniversitesi Ziraat Fakültesi Zootekni Bölümü-Şanlıurfa \\ ${ }^{2}$ Çukurova Üniversitesi Ziraat Fakültesi Zootekni Bölümü-Adana \\ *Sorumlu yazar: abkiraz@harran.edu.tr
}

\begin{abstract}
Öz
Bu çalışmada arpa silajları, kontrol, Sill-All (Alltech,UK), LC1363, LCLDH, LBPL (Lactobacillus plantarum), LBPL+Lik inokulant katkılı olarak 6 gruptan oluşmaktadır. LC1363 (Lactococcus laktis subsp. cremoris) ve LCLDH (LDH mutant Lactococcus laktis subsp. cremoris) ile LBPL+Lik (Lactobacillus plantarum) gruplar, $\beta(1,3-1,4)$ glukanaz (likenaz) enzim genine sahip rekombinant inokulantlar içermektedir. İnokulantlar silajlara $1.5 \times 10^{7} \mathrm{cfu} / \mathrm{g}$ düzeyinde katılmışlardır. 56 günlük arpa silaj gruplarında In vitro gaz üretim hacmi, gaz üretim parametresi, organik madde sindirilebilirliği (OMS), ME, NEL, düzeyleri belirlenmiştir. Kontrol, Sill-All, LC1363, LCLDH, LBPL ve LBPL+Lik inokulant katkılı silaj gruplarında OMS düzeyleri sırasıyla; 52.82, 53.96, 48.92, 52.32, 57.91ve 55.41, ME düzeyleri 7.82, 8.00, 7.23, 7.75, 8.59 ve 8.20, NEட düzeyleri 4.51, $4.60,4.06,4.48,5.24$ ve 4.93 olarak hesaplanmıştır. Silaj gruplarında 96. saat gaz üretim miktarları bakımından gruplar arasındaki farklılıklar önemli bulunmuştur. Silaj gruplarında $M E, N E_{L}$ düzeyleri ve OMS bakımından gruplar arasındaki farklılıklar önemli bulunmuştur. Burada, silaj katkı maddesi olarak LBPL ve LBPL+Lik inokulantlarının kullanımı arpa silajlarında $M E, N E$ ve $O M S$ düzeylerini önemli derece iyileştirmiştir. Sonuç olarak çalışmada elde edilen sonuçlar, özellikle arpa silajında rekombinant inokulant kullanımının, deneysel koşullarda silajın yem değerini artırdığını göstermiştir.
\end{abstract}

Anahtar kelimeler: Silaj, bakteriyel inokulant, kaba yem değeri, sindirilebilirlik, in vitro gaz üretimi

\section{The Effect on Feed Value of Barley Silage Contained Different Inoculants}

\begin{abstract}
In this study, six different barley silage treatment groups were prepared as control, Sill-All (Alltech, UK), LC1363, LCLDH, LBPL (Lactobacillus plantarum) and inoculant additive LBPL+Lik. LC1363 (Lactococcus laktis subsp. cremoris), LCLDH (LDH mutant Lactococcus laktis subsp. cremoris) and LBPL+Lik (Lactobacillus plantarum) groups contained recombinant inoculants with $\beta(1.3-1.4)$ glucanase (likenaz) enzyme gene. Inoculants were added to silages at the level of $1.5 \times 10^{7} \mathrm{cfu} / \mathrm{g}$. in vitro gas production volumes, gas production parameters, organic matter digestibility and ME, NEL levels for 56 days barley silage group were also determined. Control, Sill-All, LC1363, LCLDH, LBPL and LBPL+Lik silage groups contained recombinant inoculants, calculated OMD levels; 52.82, 53.96, 48.92, 52.32, 57.91, 55.41, ME levels 7.82, 8.00, 7.23, 7.75, 8.59, 8.20 NEL levels 4.51, 4.60, 4.06, 4.48, 5.24, 4.93 respectively. Differences among silage groups were significantly different in terms of gas production volumes at 96 hours. For the ME, NEL levels and OMS, the differences among the groups were found to be significant. In this study, using LBPL and LBPL+Lik inoculants as additives to silage was improved the levels of ME, $\mathrm{NE}_{\mathrm{L}}$ and $\mathrm{OMS}$ in barley silages. In conclusion the result obtained in the study showed that recombinant inoculant, inclusion especially to the barley silage improve feeding value under our experimental condition.
\end{abstract}

Key words: Silage, bacterial inoculants, forage value, feed quality, digestibility, in vitro gas production 


\section{Giriş}

Silaj yapımında son yıllar da silaj katkı maddesi olarak laktik asit bakterileri içeren ve bakteriyel inokulant ya da mikrobiyel inokulant olarak isimlendirilen bakteri kültürlerinden yoğun bir şekilde yararlanılmakta ve bu katkılar biyoteknolojik silaj katkıları olarak kabul edilmektedir (Pahlow, 1989). Hayvancılığı gelişmiş ülkelerde kullanımı çok yaygın olan silaj üretiminde silo içerisinde fermentasyonun hızlı ve istenilen düzeyde gelişmesi, kısa sürede ve besleme değeri daha zengin, yüksek kaliteli silaj eldesi amacıyla silaj inokulantları çok yaygın olarak kullanılmaktadır. Ayrıca, bakteri kültürleri sadece kaliteli bir silaj oluşumuna değil aynı zamanda silajın açıldıktan sonra uzun süre kalitesini yitirmeden stabil bir şekilde kalmasına da imkan sağlamaktadır (Kutlu, 2010).

Silajların değerlendirilmesinde yaygın olarak kullanılan in vitro metotlar; naylon torba tekniği (Orskov ve McDonald, 1979) ve gaz üretim tekniğidir (Menke ve ark., 1979). Rumende oluşan gazların tamamına yakın bir kısmını $\mathrm{CO}_{2}$ ve $\mathrm{CH}_{4}$ oluşturmaktadır. Gaz üretim tekniği, in vitro gaz ölçümü ile in vivo sindirilebilirlik arasında önemli ilişki olduğunu saptayan Menke ve ark., (1979)'nın çalışmasından sonra yemlerin değerlendirilmesinde rutin olarak kullanılan metottur. $\mathrm{Bu}$ metot, yemlerin fermentasyonu sonucu açığa çıkan $\mathrm{CO}_{2}$ gazı ölçümüne dayanır.

Gaz üretimi, esas olarak yemlerin uçucu yağ asitlerinden asetik asit ve bütirik asite fermente olması durumunda oluşur. Yemlerin propiyonik asite fermente edilmesi sadece asitin tamponlanmasına bağı olarak gaz oluşumuna neden olur ve nispeten düşük düzeyde gerçekleşir. Bundan dolayı lifli maddelerin parçalanmasından elde edilen gaz miktarı nişastanın parçalanmasından elde edilene göre daha fazladır (Wolin, 1960). Hızlı fermente olan karbonhidratların inkübasyonu sonucunda asetik asite oranla daha yüksek miktarda propiyonik asidi açığa çıkarken, yavaş fermente olan karbonhidratların inkübasyonu sonucunda tersi durum söz konusudur (Getachew ve ark., 1998). Dolayısıyla açığa çıkan UYA miktar ve konsantrasyonu, oluşan $\mathrm{CO}_{2}$ ve metan miktarını etkileyen önemli bir unsurdur.

Gaz üretim tekniğinde üretilen gaz miktarından faydalanılarak bir çok parametre hesaplanabilmektedir. Bu parametreler kullanılarak, yemlerin sindirilme derecelerinin belirlenmesi (Menke ve ark., 1979), yemlerin metabolize olabilir enerji (ME) ve net enerji (NE) değerlerinin saptanması (Menke ve Steingass, 1988), rumen protein (Raab ve ark., 1983) ve kuru madde parçalanabilirliğinin (Umucalılar ve ark., 2002) belirlenmesi, yem katkı maddelerinin ve rumen ortamını değiştiren maddelerin rumen fermentasyonu ve yemlerin sindirilebilirliği üzerine etkilerinin incelenmesi (Blummel, 1994), yemlerin in vitro parçalanma hızı ve miktarının belirlenmesi, etkin bir fermentatif aktivite için gerekli olan mikrobiyal $\mathrm{N}$ ve karbonhidrat intiyaçlarının ve rumendeki mikrobiyal populasyonu etkileyen yemle ilgili faktörlerin incelenmesi mümkün olabilmektedir.

Hayvana verilen rasyonun besin maddeleri içeriği ve yemlere uygulanan işlemler rumendeki fizyolojik olayları ve elde edilen ürünün niteliğini önemli ölçüde etkilemektedir. Buğdaygil ve baklagil kuru otları ve silajlarının bulunduğu kaba yemlerde gaz üretim miktarlarının farklılık gösterdiği, gaz üretiminin kuru otlarda 
silajlardan daha yüksek olduğu bildirilmektedir (Mertens ve ark., 1997; Filya ve ark., 2002; Getachew ve ark., 2004b).

Yem maddelerinin besin madde içeriklerinin çoğu kimyasal olarak analiz edilebilmektedir, bununla birlikte yemlerin ekonomik değerlerini belirten enerji içerikleri bu yolla belirlenememektedir. Yemlerin enerji değerleri yem maddelerinin kimyasal analizler sonucu elde edilen verilerin kullanılmasıyla geliştirilen eşitliklerden tahmin edilmektedir. Menke ve ark., (1979) çoklu regresyon modelinde in vitro gaz ölçüm değerini ve kimyasal kompozisyonunu kullanarak in vivo OM sindirebilirliğini oldukça yüksek doğrulukta ( $r=0.98)$ saptamışlardır. Bununla beraber, Getachew ve ark., (1998) yemlerin ME değerini, in vitro gaz üretimi ve yemlerin kimyasal bileşenlerini kullanarak hesaplamıştır. Canlı hayvanlarda ölçülen ME değeri ile gaz üretim tekniği ile tahmin edilen ME değerleri arasında ise yüksek düzeyde bir korelasyon olduğu bildirilmektedir (Getachew ve ark., 2004b).

Yemlerin net enerji içeriklerinin belirlenmesinde in vitro gaz üretim tekniğinin, diğer metotlardan (ham besin maddesi içeriğinden enerji değerinin tahmini) daha üstün olduğu bildirilmektedir (Aiple ve ark., 1996). Gaz üretim tekniği hızlı, ekonomik, yemler ve hayvan besleme açısından önemli sonuçlar vermekte olup, özellikle kaba ve kesif yemlerin birbiri ile kıyaslanması, yemlerin işleme ve kaba yemlerin saklama tipleri bakımından fikir vermesi bakımından önemli katkılar sağlamaktadır.

$\mathrm{Bu}$ çalışmada, rekombinant bakteriyel inokulant katkılı arpa hasılı silajların ham besin madde içerikleri, zamana bağı in vitro gaz üretim miktarları ve bunlara ait parametrelerin (a: yemin enjektöre konulduğu ilk anda oluşan gaz miktarı, b: zamana bağıı olarak oluşan gaz miktarı, $a+b$ : potansiyel gaz üretimi, c: gaz üretim hızı, net enerji laktasyon (NEL), metabolize edilebilir enerji (ME) ve organik madde sindirebilirliğinin (OMS) gaz üretim tekniğinden faydalanılarak elde edilen verilerden belirlenmesine çalışılmıştır.

\section{Materyal ve Metot}

Taze arpa hasılı ve inokulantlarla muamele sonrasında oluşturulan silaj gruplarında 7, 14, 28 ve 56. günlerde $\mathrm{pH}$, kuru madde (KM), ham protein (HP), ham yağ (HY), ham kül (HK), ham selüloz (HS), nötr deterjanda çözünmeyen lif (NDF) ve asit deterjanda çözünmeyen lif (ADF) değerleri Çizelge 1'de verilmiştir. Arpa hasılında $\mathrm{pH}$ değeri 6.30, KM içeriği \%31.73, HP, HY, HK, HS, NDF ve ADF içerikleri (kuru madde bazında) ise sırasıyla; \%7.81, 1.90, 6.39, $27.50,55.31$ ve 32.15 olarak tespit edilmiştir. In vitro gaz üretim ölçümleri 3, 6, 9, 12, 24, 48,72 ve 96 . saatlerde yapılmış ve değerleri Çizelge $1^{\prime}$ de verilmiştir.

\section{Araştırma Bulguları ve Tartışma}

Çizelge 1 incelendiğinde, kontrol, Sill-All, LC1363, LCLDH, LBPL ve LBPL+Lik silaj gruplarında 3. saat gaz üretim miktarları sırasıyla; 6.16, 6.66, 5.33, 7.54, 5.66, 6.18 $\mathrm{ml} / 200 \mathrm{mg}$ KM olarak tespit edilmiş olup, gruplar arasındaki farklılıklar çok önemli bulunmuştur $(P<0.01)$. $L B P L$ ve $L B P L+L i k$ silaj gruplarında 3. saat gaz üretim miktarları kontrol grubu ile benzer iken LCLDH grubundan düşük bulunmuştur. Bununla beraber, 6, 9 ve 12 . saat gaz üretim miktarları sırasıyla; 12.22, 13.94, 11.96, $16.42,12.78,14.23 \mathrm{ml} / 200 \mathrm{mg} \mathrm{KM}, 17.35$, $19.07,17.09,22.30,17.93,19.82 \mathrm{ml} / 200 \mathrm{mg}$ KM ve 23.00, 24.64, 22.02, 28.39, 23.16, 
$25.31 \mathrm{ml} / 200 \mathrm{mg} \mathrm{KM}$ olarak tespit edilmiş olup, gruplar arasındaki farklılıklar çok önemli bulunmuştur $(P<0.001)$. 6. saat gaz üretim miktarları bakımından silaj gruplarının LCLDH>LBPL+Lik>SillAll>LBPL $>$ kontrol=LC136

3 şeklinde, 9. ve 12. saat gaz üretim miktarları bakımından ise silaj gruplarının LCLDH $>$ LBPL+Lik>SillAll>LBPL=kontrol>LC136

3 şeklinde benzer olarak gruplandığı görülmüştür. Bununla beraber, 24. ve 48 . saat gaz üretim miktarları sırasıyla; 37.47 , $38.99,33.18,42.65,36.99,39.55$ ve 47.74 , $47.32,42.93,52.98,47.58,50.19 \mathrm{ml} / 200 \mathrm{mg}$ KM olarak tespit edilmiş olup, gruplar arasındaki farklılıklar çok önemli bulunmuştur $(P<0.01)$. Yirmi dördüncü saat gaz üretim miktarları bakımından silaj gruplarının LCLDH>kontrol>LBPL+Lik=SillAll> LBPL>LC1363 şeklinde, 48. saat gaz üretim miktarları bakımından ise silaj gruplarının LCLDH $>$ LBPL+Lik>kontrol>SillAII $=L B P L>L C 136$

3 şeklinde benzer olarak gruplandığı görülmüştür. Bununla beraber, 72. ve 96 . saat gaz üretim miktarları sırasıyla; 51.13, $50.53,46.65,56.50,51.46,54.41$ ve 52.77 , $51.97,48.15,57.73,53.24,55.85 \mathrm{ml} / 200 \mathrm{mg}$ KM olarak tespit edilmiş olup, gruplar arasındaki farklılıklar önemli bulunmuştur $(P<0.05)$. Yetmiş ikinci ve 96 . saat gaz üretim miktarları bakımından silaj gruplarının LCLDH $>$ LBPL+Lik>kontrol=LBPL $>$ SillAll $>$ LC136

3 şeklinde benzer olarak gruplandığı görülmüştür. Silaj gruplarında in vitro gaz ölçümündeki $\mathrm{pH}$ değerleri arasındaki farklılıklar önemsiz bulunmuştur. Çizelge 1 incelendiğinde, kontrol, Sill-All, LC1363, LCLDH, LBPL ve LBPL+Lik silaj gruplarında gaz üretim parametrelerinden a değeri sırasıyla; $2.09,-1.90,-1.09,-1.79,-1.33,-1.73 \mathrm{ml}$ olarak tespit edilmiş olup, gruplar arasındaki farklılıklar önemsiz bulunmuştur. Silaj gruplarında gaz üretim parametrelerinden $b$ değeri sırasıyla; 54.96, 53.52, 49.04, 54.97,
58.79, $57.44 \mathrm{ml}$ olarak tespit edilmiş olup, gruplar arasındaki farklılıklar önemli bulunmuştur $(P<0.05)$. Parametre $b$ değeri bakımından silaj gruplarının kontrol=LCLDH $=$ LBPL=LBPL+Lik>SillAll>LC1363 şeklinde gruplandığı görülmüştür. Silaj gruplarında gaz üretim parametrelerinden $c$ değeri 0.050$0.057 \mathrm{ml} / \mathrm{h}$ arasında tespit edilmiş olup, gruplar arasındaki farklılıklar önemsiz bulunmuştur.

Çizelge 1 incelendiğinde, kontrol, Sill-All, LC1363, LCLDH, LBPL ve LBPL+Lik silaj gruplarında $\mathrm{ME}$ ve $\mathrm{NE}_{\mathrm{L}}$ düzeyleri sırasıyla; $7.82,8.00,7.23,7.75,8.59,8.20$ ve 4.51 , 4.60, 4.06, 4.48, 5.24, $4.93 \mathrm{MJ} / \mathrm{kg} \mathrm{KM}$ olarak tespit edilmiş olup, gruplar arasındaki farklılıklar çok önemli bulunmuştur $(P<0.01)$. ME düzeyleri bakımından silaj gruplarının LBPL $>$ LBPL+Lik>kontrol=SillAll $>$ LCLDH> LC1363 şeklinde, $N E_{L}$ düzeyleri bakımından silaj gruplarının ise LBPL>LBPL+Lik>SillAll> kontrol=LCLDH $>$ LC1363 şeklinde gruplandığı görülmüştür. Burada, silaj katkı maddesi olarak LBPL ve LBPL+Lik inokulantlarının kullanımı arpa silajlarında $M E$ ve $N_{L}$ düzeyleri önemli derece iyileştirmiştir.

Çizelge 1 incelendiğinde, kontrol, Sill-All, LC1363, LCLDH, LBPL ve LBPL+Lik silaj gruplarında OMS düzeyleri sırasıyla; $\% 52.82$, 53.96, 48.92, 52.32, 57.91, 55.41 olarak tespit edilmiş olup, gruplar arasındaki farklılıklar çok önemli bulunmuştur $(P<0.001)$. OMS düzeyleri bakımından silaj gruplarının ortalama karşılaştırmada LBPL $>$ LBPL+Lik>SillAll=kontrol>LCLDH>LC136 3 şeklinde gruplandığı görülmüştür. Burada, silaj katkı maddesi olarak LBPL ve LBPL+Lik inokulantlarının kullanımı arpa silajlarında OMS düzeylerini önemli derece iyileştirmiştir. Arpa silajı gruplarının gaz üretim miktarlarına ait grafik Şekil 1'de verilmiştir. 
Çizelge 1. Arpa silajı gruplarının gaz üretim miktarları (ml/200 mg KM), gaz üretim parametreleri, Metabolize, edilebilir enerji içerikleri (ME, MJ/kg $\mathrm{KM}$, ) net enerji loktasyon (NEL, MJ/kg KM) organik madde sindirilebilrliği (OMS, \%)

Table 1. Gas production levels ( $\mathrm{ml} / 200 \mathrm{mg}$ of $\mathrm{DM}$ ), gas production parameters, metabolizble energy (ME, MJ/kg DM) net energy lactatin (NEL, MJ/kg DM), organic matter digestibility (\% OMD) of braley silage groups.

\begin{tabular}{|c|c|c|c|c|c|c|c|}
\hline Gaz Üretimi & KONTROL (A) & Sill-All (B) & LC 1363 (C) & LCDH (D) & LBPL (E ) & LBPL+Lik (F) & Önemlilik \\
\hline 3 & $6,16 \pm 0,48 a b$ & $6,66 \pm 0,20 \mathrm{bc}$ & $5,33 \pm 0,23 a$ & $7,54 \pm 0,15 \mathrm{c}$ & $5,66 \pm 0,36 a b$ & $6,18 \pm 0,46 a b$ & $* *$ \\
\hline 6 & $12,22 \pm 0,18 a$ & $13,94 \pm 0,40 \mathrm{bc}$ & $11,96 \pm 0,31 \mathrm{a}$ & $16,42 \pm 0,13 d$ & $12,78 \pm 0,55 a b$ & $14,23 \pm 0,75 \mathrm{c}$ & $* * *$ \\
\hline 9 & $17,35 \pm 0,27 a b$ & $19,07 \pm 0,60 \mathrm{bc}$ & $17,09 \pm 0,23 a$ & $22,30 \pm 0,57 d$ & $17,93 \pm 0,65 a b$ & $19,82 \pm 0,96 \mathrm{c}$ & $* * *$ \\
\hline 12 & $23,00 \pm 0,38 a b$ & $24,64 \pm 0,68 b c$ & $22,02 \pm 0,51 \mathrm{a}$ & $28,39 \pm 0,51 \mathrm{~d}$ & $23,16 \pm 0,73 a b$ & $25,31 \pm 1,16 \mathrm{c}$ & $* * *$ \\
\hline 24 & $37,47 \pm 0,36 \mathrm{~b}$ & $38,99 \pm 0,99 \mathrm{bc}$ & $33,18 \pm 2,22 \mathrm{a}$ & $42,65 \pm 0,73 c$ & $36,99 \pm 0,99 a b$ & $39,55 \pm 1,33 \mathrm{bc}$ & $* *$ \\
\hline 48 & $47,74 \pm 0,42 \mathrm{~b}$ & $47,32 \pm 1,85 a b$ & $42,93 \pm 2,20 \mathrm{a}$ & $52,98 \pm 0,73 \mathrm{c}$ & $47,58 \pm 1,52 a b$ & $50,19 \pm 1,38 \mathrm{bc}$ & $* *$ \\
\hline 72 & $51,13 \pm 0,42 a b c$ & $50,53 \pm 1,85 a b$ & $46,65 \pm 2,20 a$ & $56,50 \pm 0,73 c$ & $51,46 \pm 1,52 a b c$ & $54,41 \pm 1,38$ bc & $*$ \\
\hline 96 & $52,77 \pm 0,42 \mathrm{abc}$ & $51,97 \pm 1,85 a b$ & $48,15 \pm 2,20 \mathrm{a}$ & $57,73 \pm 0,73 \mathrm{c}$ & $53,24 \pm 1,52 a b c$ & $55,85 \pm 1,38 b c$ & $*$ \\
\hline $\mathrm{Ph}$ & $6,77 \pm 0,01$ & $6,73 \pm 0,03$ & $6,75 \pm 0,02$ & $6,77 \pm 0,01$ & $6,76 \pm 0,01$ & $6,77 \pm 0,01$ & NS \\
\hline \multicolumn{8}{|c|}{ GAZ ÜRETIM PARAMETRELERI } \\
\hline $\mathrm{a}, \mathrm{ml}$ & $-2.09 \pm 0,42$ & $-1.90 \pm 0,18$ & $-1.09 \pm 0,55$ & $-1.79 \pm 0,35$ & $-1.33 \pm 0,44$ & $-1.73 \pm 0,28$ & NS \\
\hline $\mathrm{b}, \mathrm{ml}$ & $54.96 \pm 0.31 b$ & $53.52 \pm 1.92 a b$ & $49.04 \pm 3.13 \mathrm{a}$ & $54.97 \pm 1.46 b$ & $58.79 \pm 0.77 b$ & $57.44 \pm 1.18$ & $*$ \\
\hline $\mathrm{c}, \mathrm{ml}$ & 0,050 & 0.057 & 0.050 & 0.050 & 0.057 & 0.050 & NS \\
\hline \multicolumn{8}{|l|}{ ENERJI VE OMS } \\
\hline $\mathrm{ME}$ & $7.82 \pm 0.05 b$ & $8.00 \pm 0.14 b$ & $7.23 \pm 0.30 \mathrm{a}$ & $7.75 \pm 0.14 a b$ & $8.59 \pm 0.09 c$ & $8.20 \pm 0.18 b c$ & $* *$ \\
\hline NEL & $4.51 \pm 0.03 b$ & $4.60 \pm 0.10 \mathrm{bc}$ & $4.06 \pm 0.22 \mathrm{a}$ & $4.48 \pm 0.10$ & $5.24 \pm 0.07 d$ & $4.93 \pm 0.14 \mathrm{~cd}$ & $* *$ \\
\hline OMS & $52.82 \pm 0.32 b$ & $53.96 \pm 0.88 b$ & $48.92 \pm 1.98 \mathrm{a}$ & $52.32 \pm 0.88 \mathrm{ab}$ & $57.91 \pm 0.65 c$ & $55.41 \pm 1.19 \mathrm{bc}$ & $* * *$ \\
\hline
\end{tabular}

a-d; Aynı sütundaki gruplar arasındaki fark istatiski olarak önemlidir. ${ }^{*} \mathrm{P}<0.05{ }^{* *} \mathrm{P}<0.01{ }^{* * *} \mathrm{P}<0.001 \quad$ NS:önemsiz 


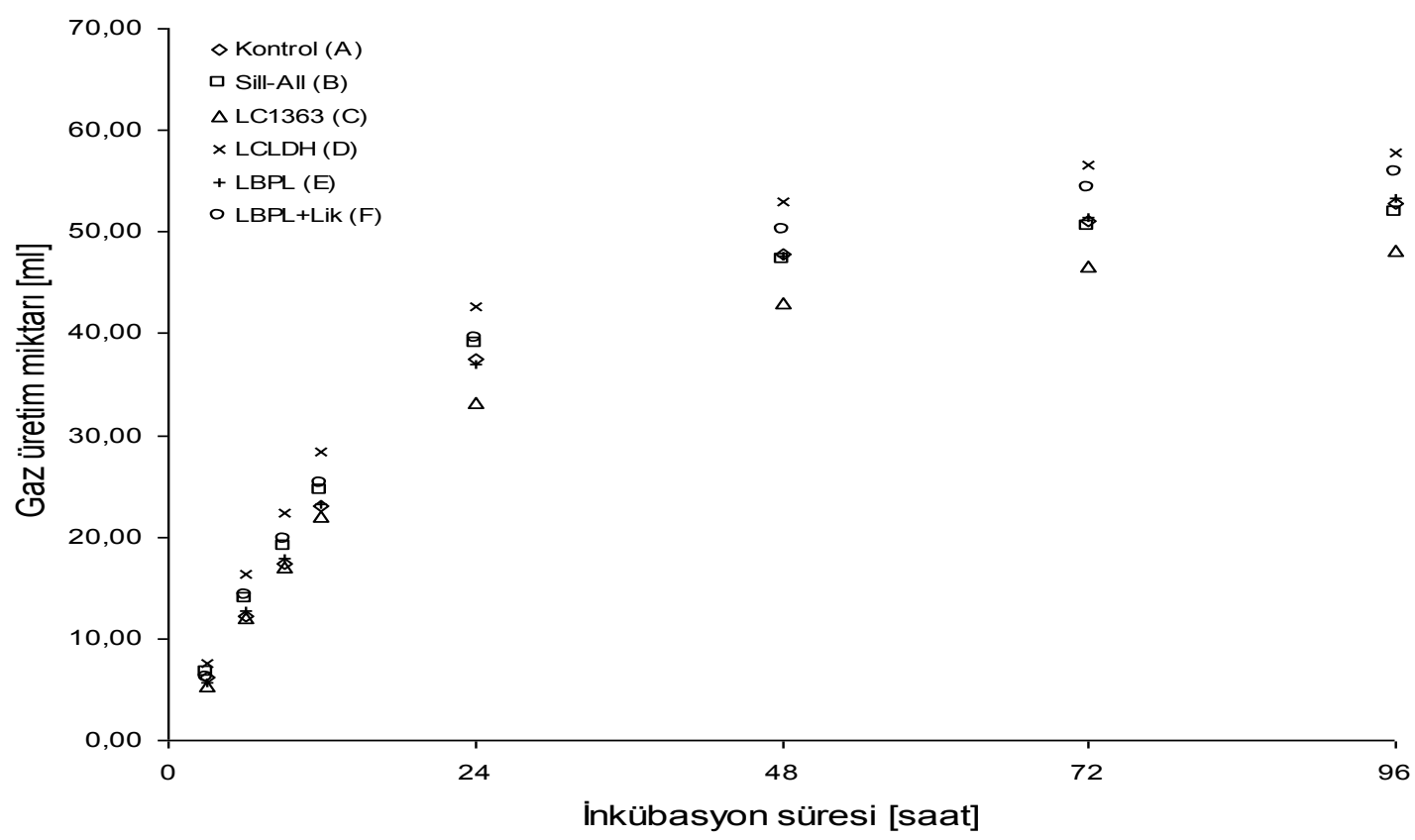

Şekil 1. Arpa silajı gruplarının gaz üretim miktarları (ml/200 mg KM)

Figure 1. Gas production levels of barley silage groups ( $\mathrm{ml} / 200 \mathrm{mg}$ of DM)

Kamalak ve ark., (2004), kaba yemlerin $M E$ değerlerini gaz üretim tekniğinde elde edilen verilerden ve yemlerin besin madde içeriklerinden faydalanılarak geliştirilen değişik eşitliklerden hesaplamışlardır. Araştırıcılar yonca otu, yonca silajı ve mısır silajına ait 24 saatlik gaz üretim miktarlarını sırasıyla; 52.6, 56.33 ve $60.83 \mathrm{ml} / 200 \mathrm{mg} \mathrm{KM}$ olarak, bunlara ait $a, b, a+b$ ve $c$ değerlerini sirasıyla; $0.57,59.32,59.89 \mathrm{ml}$ ve 0.113 saat $/ \mathrm{ml} ; 1.33,62.88,64.21 \mathrm{ml}$ ve 0.113 saat $/ \mathrm{ml}$ ve $4.19,68.80,73.00 \mathrm{ml}$ ve 0.09 saat $/ \mathrm{ml}$ olarak, ME değerlerinin ise sırasıyla; 8.88-11.49 MJ/kg KM, 9.20-11.59 MJ/kg KM ve $8.77-11.07 \mathrm{MJ} / \mathrm{kg} \quad \mathrm{KM}$ arasında belirlemişlerdir.

Kamalak ve ark., (2005a), yaptıkları çalışmada çeşitli yemlerin KM parçalanabilirliliğinin tahmin edilmesi bakımından in vitro gaz üretim tekniği ile in situ naylon torba tekniğini karşılaştırmışlar, bu iki teknik arasında yüksek düzeyde bir ilişki saptamışlardır. Araştırıcılar, gaz üretim tekniğinde en yüksek gaz üretim değerlerinin mısır silajında elde etmiş ve bunu sırasıyla yonca otu, buğday samanı ve arpa samanı izlemiştir. Çalışmada, gaz üretim tekniğinin kaba yemlerin değerlendirilmesinde kuru madde parçalanabildiği ve bazı parçalanma parametrelerinin belirlenmesinde naylon torba tekniği yerine kullanılabileceğini bildirmişlerdir.

Kamalak ve ark., (2005b), yaptıkları çalışmada, bazı kaba yemlerin kuru madde sindirilebilirlikleri ve kuru madde tüketimlerinin tahmininde gaz üretim tekniğini kullanmışlardır. Araştırıcılar kuru maddenin sindirim derecesindeki varyasyonun \%74'lük kısmını c değerinin, \%92'lik kısmını b değerinin, \%96'lık kısmını ise $a+b$ değerinin açıkladığını, yem tüketimindeki varyasyonun $\% 78$ 'lik kısmını c değerinin, \%70'lik kısmını $b$ değerinin ve \%84-90'lık kısmının ise $a+b$ değerinin açıkladığını bildirmektedirler. Araştırıcılar tüm inkübasyon sürelerinde elde edilen gaz üretim miktarları ile yem tüketimi ve sindirim dereceleri arasında önemli ilişki bulmuşlar, 
bununla birlikte gaz üretim tekniğinin yem tüketimi ve yemlerin sindirilebilirliğinin tahmininde kullanılabileceğini belirtmişlerdir.

Kamalak ve ark., (2005c), yaptıkları çalışmada 14 farklı yonca kuru otunun gaz üretim parametreleri, organik madde sindirilebilirliği (OM) ve ME içeriklerinin araştırmışlar ve 96 saatlik inkübasyon sonrası gaz üretiminin 49.8-58.6 ml/200mg KM arasında değiştiğini belirtmişlerdir. Araştırıcılar, $a, b, a+b$ ve $c$ değerlerinin sırasıyla $1.6-3.5 \mathrm{ml}, 44.6-53.2 \mathrm{ml}$, 47.0-56.3 $\mathrm{ml}$ ve $0.07-0.09 \mathrm{ml} / \mathrm{saat}$ arasında değiştiğini, OMS içeriklerinin \%59.15-66.33 arasında, ME içeriklerinin ise 8.65-9.76 MJ/kg KM arasında değiştiğini belirlemişlerdir.

Jatkauskas ve ark. (2008), ot-baklagil silajlarında (\%50 Lolium perenne, \%20 Festuca pretense, \%30 Trifolium pretense) ME bakımından kontrol grubu $(9.9 \mathrm{MJ} / \mathrm{kg}$ KM) ile bakteriyel inokülantlı (Lactobacillus plantarum Milab 393, Pediococcus acidilactici P6 ve P11, Enterococcus faecium $\mathrm{M74}$, and Lactococcus lactis SR3.54) (10.6 $\mathrm{MJ} / \mathrm{kg} \mathrm{KM}$ ) grupta farklılığın önemli olduğu bildirmişlerdir. Özdüven ve ark., (2010) kontrol, LAB, enzim, LAB+enzim tritikale silaj gruplarında 45. gün in vitro $\mathrm{KMS}$ düzeyleri sirasıly \%57.6, 58.3, 60.9 ve 60.7, in vitro OMS düzeyleri ise sırasıyla \%60.1, 61.4, 63.9 ve 60.7 olarak bulmuşlar ve gruplar arasındaki farklılığın önemli olduğunu bildirmişlerdir. Baah ve ark., (2011), kontrol, homolaktik inokulant (I), SDS (S) ve I+S arpa silaj gruplarında in situ KMS ve OMS düzeyleri bakımından (sırasıyla 55.18a, $52.48 \mathrm{~b}, 52.44 \mathrm{~b}, 52.06 \mathrm{~b}$ ve $54.48 \mathrm{a}, 51.78 \mathrm{~b}$, 51.06c, 51.24c) önemli farklıkların bulunduğunu bildirmişlerdir. Jalč ve ark., (2009), kontrol, L. plantarum CCM 4000, L. fermentum LF2 Enterococcus faecium CCM 4231 mısır silajı (105 günlük) gruplarında, IVKMS değeri bakımından tüm grupların benzer olduğu (sırasıyla \%76.1, 76.5, 74.9 ve 78.2) ve inokülant katkısının IVKMS oranını önemli derecede etkilemediği belirtilmiştir.

\section{Sonuçlar}

Sonuç olarak, arpa silajının yapımında mikrobiyal inokulant katkısının silajlarda bazı besin madde içeriklerini, fermentasyon özelliklerini, in vitro gaz üretimini, enerji ve sindirilebilirliği olumlu yönde etkileyerek silaj kalitesini arttırdığı görülmüştür. Bakteriyel inokulantların doğal veya bazı enzimler yönünden rekombinant özellik kazandırılmasına ve silaj kalitesi üzerine etkilerine yönelik bilimsel çalışmaların öncelikli olarak sürdürülmesi halinde silajlarda görülen sorunların çözülmesi ve silaj kalitesinin arttırıması mümkün olabilecektir.

\section{Ekler}

Bu makale Ayfer BOZKURT KIRAZ 'In doktora tezinden üretilmiştir.

\section{Kaynaklar}

AOAC - Official Methods of Analysıs, 2000. 17th Edition, Gaitherburg. MD, USA.

Aiple, K. P. , Steingass, H. and Drochner, W., 1996 Prediction of net energy content of raw materials and compound feeds for ruminants by different laboratory methods. J. Arcb. Anim. Nutr., 49:213-220.

Baah, J., Addah, W., Okine, E., K. Mcallister, T. A., 2011. Effects of homolactic bacterial inoculant alone or combined with an anionic surfactant on fermentation, aerobic stability and in situ ruminal degradability of barley silage. AsianAustralian Journal of Animal Sciences. 24(3):369-378.

Blummel, M., 1994. Relationship between kinetics of storer fermentation as described by the Hohenheim in vitro gas production test and voluntary feed intake of 54 cereal storers. PhD Thesis. Hohenheim University. 
Filya I., Karabulut A. and Sucu E., 2002. The effect of Lactobacillus plantarum and Lactobacillus buchneri on the fermentation, aerobic stability, and ruminal degradability of maize silage in warm climate. In: Gechie L.M. and Thomas C. (eds) Proceedings of the 13th International Silage Conference, Auchincruive, Ayr, Scotland, 2002, pp. 192-193. Auchincruive, Ayr, Scotland: Scottish Agricultural College.

Getachew, G., Blummel, M., Makkar, H.P.S., Becker, K., 1998. In vitro gas measuring techniques for assessment of nutritional quality of feeds : A review. J. Anim. Feed Sci. Technol., 72:261-281.

Getachew, G., Robinson, P.H., Depeters, E.J., Taylor, S.J., 2004b. Relationships between chemical composition, dry matter degradation and in vitro gas production of several feeds. Anim. Feed. Sci. and Techn. ,111(1-4):57-71.

Jalč, D., Lauková, A., Pogány Sımonová, M., Váradyová, Z. and Homolka, P., 2009. Bacterial inoculant effects on corn silage fermentation and nutrient composition. Asian-Aust. J. Anim. Sci., 22(7): 977-983.

Jatkauskas J., Vrotniakiene, V., Aragón, Y. 2010. Fermentation quality and nutritive value of grass-legume silage treated with inoculant. BioStabil Plus. In:14th International Symposium Forage Conservation. Brno: Mendel University in Brno, pp. 45-47.

Kamalak, A., Canbolat, O., Erol, A., Kılınç, C., Kızılsımsek, M., Ozkan, C.O., Ozkose, E., 2005c. Effect of variety on chemical composition, in vitro gas production, metabolizable energy and organic matter digestibility of alfalfa hays. Volume 17, Article \#77.

Kamalak, A., Canbolat, O., Gurbuz, Y. and Ozay, O., 2005a. Prediction of dry matter intake and dry matter digestibilities of some forages using the gas production techniques in sheep. Turkish Journal of Veterinary Animal Sciences, 29:517-523.

Kamalak, A., Canbolat, O., Gurbuz, Y., Erol, A. and Ozay, O., 2005b. Effect of maturity stage on the chemical composition, in vitro and in situ degradation of tumbleweed hay (Gundelia tuonefortii L.). Small Ruminant Research 58:149-156.
Kamalak, A., Canbolat, O., Gurbuz, Y., Ozay, O., Ozkose, E., 2004. Variation in metabolizable energy content of forages estimated using in vitro gas production. Pakistan Journal of Biological Sciences. 7(4):601-605.

Kutlu H.R., Baykal Çelik, L., 2010. Yemler Bilgisi ve Yem Teknolojisi. Çukurova Üniversitesi Ziraat Fakültesi Yayınları, Adana.

Menke, K.H., Raab, L., Salewski, A., Steingass, H., Fritz, D., Schneider, W., 1979. The estimation of the digestibility and metabolisable energy content of ruminant feedingstuffs from the gas production when they are incubated with rumen liquor. Journal of Agricultural Science, 93: 217-222.

Menke, K.H., Steingass, H., 1988. Estimation of the energetic feed value from chemical analysis and in vitro gas production using rumen fluid. Animal Resources and Development, 28: 7-55.

Ørskov, E. R., Mcdonald, I., 1979. The estimation of protein degradability in the rumen from incubation measurements weighted according to rate of passage. Journal of Agricultural Science (Camb.) 92:499-503.

Özdüven, M.L., Kursun Önal, Z., Koç, F., 2010. The effects of bacterial inoculants and/or enzymes on the fermentation, aerobic stability and in vitro dry and organic matter digestibility characteristics of triticale silages. Kafkas Univ. Vet. Fak. Derg. 16 (5): 751-756.

Pahlow, G., 1989. Wie lassen sich Silagen verbessern. Agrar - press Nr. 5/89 7. April 1989, Honorar erbeten auf PSK Köln 171604 -504: 1-3.

Raab, L, Cafantaris, B., Jilg, T., Menke, K.H., 1983. Rumen protein degradationand biosynthesis: 1. A new method for determination of protein degradation in the rumen fluid in vivo. Br. J. Nutr. 50: 569-582.

Umucalılar, H.D., Coşkun, B., Gulsen, N., 2002. In situ rumen degradation and in vitro gas production of some selected grains from Turkey. J.Anim. Physiol. A. Anim. Nutr. 86:288-297.

Wolin, M.J., 1960. A theoretical rumen fermentation balance. J. Dairy Sci., 43:1452-1459. 